\title{
THE INCIDENCE AND MORTALITY OF BREAST- AND ARTIFICIALLY-FED INFANTS ADMITTED TO HOSPITAL WITH INFECTIONS *
}

BY

J. H. EBBS, M.D., D.C.H. ANd FRANCES MULLIGAN, M.D.

(From the Department of Paediatrics, University of Toronto, and the Hospital for Sick Children, Toronto, under the direction of Alan Brown, M.D., F.R.C.P.)

Statements are often made and beliefs expressed about the relative values of breast and artificial feeding. In 1934, Grulee reported a study of some twenty thousand infants who had been followed in well-baby clinics in Chicago up to the age of nine months. The breast-fed babies were 48.5 per cent. of the total, while another 43.0 per cent. were partially breast-fed. There were approximately half as many infections in the breast-fed as in the artificially-fed group and only one-tenth the percentage of deaths. The results were definitely in favour of breast feeding. In analysing a large number of post-mortem records, Ebbs (1938) found that infants who died and were found to have otitis media and sinusitis were practically all artificially-fed at the time of onset of the infection.

During ward rounds in the Hospital for Sick Children, Toronto, the following questions were raised: (1) Are there more artificially-fed babies admitted to this hospital with infections than breast-fed babies? (2) Is the chance of survival from an infection greater in a breast-fed infant than in an artificiallyfed infant? In order to try to answer these questions the records were examined of one thousand five hundred consecutive admissions of babies under twelve months of age with infections, admitted to the Hospital for Sick Children, Toronto.

Table 1 shows the age incidence of these children with infections. It will be noted that after the first two months the number in each month is fairly uniform.

TABLE 1

AGE INCIDENCE OF INFANTS STUDIED

\begin{tabular}{c|c|c|c|c|c|c|c|c|c|c|c|c}
\hline AGE IN MONTHS & 1 & 2 & 3 & 4 & 5 & 6 & 7 & 8 & 9 & 10 & 11 & 12 \\
\hline Number of babies & 48 & 89 & 157 & 147 & 108 & 119 & 147 & 139 & 138 & 143 & 113 & 152 \\
\hline
\end{tabular}

* Read at the Annual Meeting of the Canadian Society for the Study of Diseases of Children, Alexandria Bay, N.Y., 1939. 
Table 2 gives the incidence of breast, artificial and mixed feeding. Two hundred and twenty-seven were breast-fed entirely or for at least eight months in those who were over this age. This number is $15 \cdot 1$ per cent. of the total. The artificially-fed group were those babies who had not been breast-fed or in the case of infants over six months who had not been breast-fed for more than six weeks. Eight hundred and thirty-six ( 55.7 per cent.) were in this group. Four hundred and thirty-seven (29.1 per cent.) had been breast-fed for at least six weeks and then artificially-fed up to the time of admission. There were more artificially-fed infants admitted to the hospital with infections than breastfed infants with infections. In order to determine the incidence of breast feeding amongst the class of babies from which the hospital admissions were drawn, the findings of Dr. C. B. Shillington, who attended well-baby clinics in different sections of the city and recorded the feeding of each child attending on that day, have been used. He found that 35.6 per cent. were, or had been, breast-fed, $28 \cdot 1$ per cent. were artificially-fed and $36 \cdot 2$ per cent. were breast-fed for a reasonable time and then artificially-fed.

TABLE 2

INCIDENCE OF BREAST FEEDING IN HOSPITAL ADMISSIONS COMPARED WITH BABIES ATTENDING WELL-BABY CLINICS

\begin{tabular}{|c|c|c|c|}
\hline & & $\begin{array}{l}\text { HOSPITAL INFANTS WITH } \\
\text { INFECTIONS PER CENT. }\end{array}$ & $\begin{array}{l}\text { INFANTS ATTENDING WELL- } \\
\text { BABY CLINICS PER CENT. }\end{array}$ \\
\hline $\begin{array}{l}\text { Breast-fed } \\
\text { Breast-fed and } \cdots\end{array}$ & $\ddot{a r t i f i c i a l}$ & $15 \cdot 1$ & 35.6 \\
\hline $\begin{array}{l}\text { feeding } \\
\text { Artificial feeding }\end{array}$ & $\cdots$ & $\begin{array}{l}29 \cdot 1 \\
55 \cdot 7\end{array}$ & $\begin{array}{l}36 \cdot 2 \\
28 \cdot 1\end{array}$ \\
\hline
\end{tabular}

From table 3 it will be seen that respiratory infections are responsible for the majority of admissions to the hospital of babies up to one year. 73.7 per cent. were respiratory and associated infections, while 20.9 per cent. had gastro-

TABLE 3

MORTALITY OF BABIES WITH RESPIRATORY INFECTIONS IN RELATION TO TYPE OF FEEDING

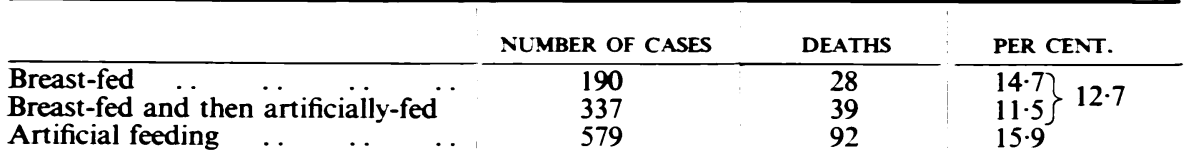

MORTALITY OF BABIES WITH GASTRO-INTESTINAL INFECTIONS IN RELATION TO TYPE OF FEEDING

Breast-fed

$\begin{array}{lr}\text { Breast-fed } \because \text {. } & 17 \\ \text { Breast-fed and then artificially-fed } & 79 \\ \text { Artificial feeding } & 218\end{array}$

Artificial feeding

4
9
33

$\left.\begin{array}{l}23 \cdot 5 \\ 11 \cdot 4\end{array}\right\} 13 \cdot 5$

$15 \cdot 1$

MORTALITY OF BABIES WITH MISCELLANEOUS INFECTIONS IN RELATION TO TYPE OF FEEDING

Breast-fed $\because$ then artificially-fed

Artificial feeding

20

39

$\left.\begin{array}{l}50-0 \\ 23 \cdot 8\end{array}\right\} 36 \cdot 5$

$30 \cdot 7$ 
intestinal conditions such as intestinal intoxication, infectious diarrhoea and diarrhoea not associated with respiratory infection. Only $5 \cdot 3$ per cent. had other infections such as abscess, infections of the skin or genito-urinary infections.

Of the breast-fed babies 83.7 per cent. had respiratory infections compared with 69.2 per cent. of the artificially-fed and $77 \cdot 1$ per cent. of the infants with mixed feeding. Only 7.5 per cent. of the breast-fed group had gastro-intestinal infections compared with 26 per cent. of the artificially-fed and $18 \cdot 1$ per cent. who had breast and then artificial feeding. The percentage of deaths among totally breast-fed babies was slightly higher than in the other two groups. There were forty-two deaths in 227 breast-fed babies admitted with infections, a percentage mortality of $18 \cdot 5$. However, this is only $18 \cdot 1$ per cent. of all the deaths which occurred in this series. There were 137 deaths in 836 artificiallyfed babies, or 16.4 per cent. This is 59.1 per cent. of all deaths. The mortality in the babies entirely breast-fed and those who had been breast-fed an appreciable length of time was 14.3 per cent. as compared with 16.4 per cent. of those artificially-fed throughout (table 4).

TABLE 4

MORTALITY IN 1500 INFANTS WITH INFECTIONS

\begin{tabular}{|c|c|c|c|c|c|}
\hline \multirow[b]{2}{*}{ FEEDING } & \multicolumn{2}{|c|}{ CASES } & \multicolumn{3}{|c|}{ DEATHS } \\
\hline & NUMBER & $\begin{array}{l}\text { PER CENT. } \\
\text { OF TOTAL }\end{array}$ & NUMBER & PER CENT. & $\begin{array}{l}\text { PER CENT. OF } \\
\text { TOTAL } \\
\text { DEATHS }\end{array}$ \\
\hline $\begin{array}{l}\text { Breast } \\
\text { Breast and artificial } \\
\text { Artificial } \ldots\end{array}$ & $\begin{array}{l}227 \\
437 \\
836\end{array}$ & $\begin{array}{l}15 \cdot 1 \\
29 \cdot 1 \\
55 \cdot 7\end{array}$ & $\begin{array}{r}42 \\
53 \\
137\end{array}$ & $\left.\begin{array}{l}18 \cdot 5 \\
12 \cdot 1\end{array}\right\}_{16 \cdot 4} 14 \cdot 3$ & $\begin{array}{l}18 \cdot 1 \\
22 \cdot 8 \\
59 \cdot 1\end{array}$ \\
\hline Total & 1500 & & 232 & $15 \cdot 4$ & \\
\hline
\end{tabular}

Summary

In reviewing the case histories of one thousand five hundred infants under one year of age, admitted to the Hospital for Sick Children, Toronto, with infections, during three and a half years, evidence was found that fewer breastfed babies were admitted with infection than artificially-fed babies. The incidence of breast feeding among the one thousand five hundred admissions with infections was less than half the incidence of breast feeding in the wellbaby clinics in the city. Respiratory infections were found more frequently than other infections. The incidence of gastro-intestinal infections was lower in the breast-fed babies. The percentage mortality was slightly higher in the breast-fed group.

\section{REFERENCES}

Ebbs, J. H. (1938). Brit. med. J., 1, 385, Grulee, C. G., et al. (1934). Trans. Sect. Pediat. Amer. med. Ass., p. 25. 